\title{
Correlation and Path Coefficient Analysis for Yield, Yield Attributing and Nutritional Traits in Rice (Oryza sativa L.)
}

\author{
Ramya Rathod*, D. Sanjeeva Rao, V. Ravindra Babu and M. Bharathi \\ ${ }^{1}$ Department of genetics and plant breeding, college of agriculture, PJTSAU, \\ Rajendranagar, Hyderabad, India \\ ${ }^{2}$ Crop Improvement Section, Indian institute of rice research, Rajendranagar, Hyderabad, India \\ *Corresponding author
}

\section{A B S T R A C T}

\section{Keywords}

Rice, Correlation coefficients, Path coefficient analysis.

Article Info

Accepted:

04 September 2017

Available Online:

10 November 2017
The present investigation is carried out to study the correlation and path analysis in fifty six high iron and zinc genotypes of rice (Oryza sativa L.). Character association studies revealed that the characters grain yield per plant showed significant positive association with number of productive tillers per plant, panicle length, number of filled grains per panicle and grain iron concentration. Hence, selection for these traits can improve yield. Path coefficient analysis revealed that the traits 1000-grain weight, numbers of filled grains per panicle, number of productive tillers per plant, grain iron concentration, grain zinc concentration, days to $50 \%$ flowering and plant height were directly influencing the grain yield per plant. Hence, these traits were considered as important attributes in formulating selection criterion for achieving desired targets.

\section{Introduction}

Rice feeds more than half the human population worldwide, most of whom live in developing countries and many have no other diet. The crop is the second most widely consumed food grain in the world next to wheat. From poorest to richest person in this world consume rice in one or other form. In the last two decades, new research findings generated by the nutritionists have brought to light the importance of micronutrients, vitamins and proteins in maintaining good health, adequate growth and even acceptable levels of cognitive ability apart from the problem of protein energy malnutrition. Most of the characters of interest to breeders are complex and are the result of the interaction of a number of components. Understanding the relationship between yield, quality and its components is of paramount importance for making the best use of these relationships in selection.

Character association derived by correlation coefficient, forms the basis for selecting the desirable plant, aiding in evaluation of relative influence of various component characters on grain yield. Path coefficient analysis discerns correlation into direct and indirect effects. In the present study, an attempt was made to understand the 
association and path analysis of quality and component characters for grain yield in rice genotypes.

\section{Materials and Methods}

The experimental material comprised of 56 genotypes of rice having high iron and zinc were grown during kharif, 2014 at Indian institute of Rice Research Farm, Ramachandrapuram, Hyderabad in two replications in Randomized Block Design with a spacing of $20 \mathrm{x} 15 \mathrm{~cm}$. All the recommended package of practices was adopted besides providing necessary prophylactic plant protection measures to raise a good crop. Observations were recorded for yield, yield attributing characters and nutritional characters on five randomly selected competitive plants for each entry in each replication. The mean data obtained at each location was considered for final statistical analysis. Days to 50\% flowering was recorded on plot basis. Observations were recorded and the data was subjected to statistical analysis. Statistical analyses for the above characters were done following Singh and Chaudhary (1995) for correlation coefficient and Dewey and Lu (1959) for path analysis.

\section{Results and Discussion}

\section{Correlation}

Genotypic correlation coefficients in general were higher than phenotypic correlation coefficients

(Table 1) indicating strong inherent association between the traits. Grain yield per plant had significant positive association with number of productive tillers per plant, panicle length, number of filled grains per panicle and grain iron concentration. This indicated that all these characters were important for yield improvement. Similar kind was reported by
Padmaja et al., (2011), Babu et al., (2012), Patel et al., (2014) and Rao et al., (2014) for number of productive tillers per plant, Ekka et al., (2011), Mohanty et al., (2012), Sravan et al., (2012), Reddy et al., (2013), Patel et al., (2014) and Rahman et al., (2014) for number of filled grains per panicle and panicle length, Gangashetty et al., (2013) for grain iron concentration. Hence, these characters could be considered as criteria for selection for higher yield as these were mutually and directly associated with grain yield.

Days to $50 \%$ flowering showed significant negative association with 1000-grain weight and number of productive tillers per plant showed significant negative association with 1000-grain weight and grain zinc concentration suggesting that yield improvement could be done only by improving one of the characters and simultaneous improvement is not possible.

Days to $50 \%$ flowering recorded a nonsignificant positive association with plant height, number of productive tillers per plant and number of filled grains per panicle as reported by Sarker et al., (2014) for plant height, number of productive tillers per plant and number of filled grains per panicle.

Plant height registered a significant positive association with number of productive tillers per plant, panicle length, number of filled grains per panicle, 1000-grain weight and grain iron concentration as reported by Chandra et al., (2009) and Rahman et al., (2014) for number of productive tillers per plant and number of filled grains per panicle, Sravan et al., (2012), Reddy et al., (2013), Sarker et al., (2014) for panicle length, Babu et al., (2012) for 1000-grain weight and Gangashetty et al., (2013) for grain iron concentration. This trait also had positive non-significant correlation with grain zinc concentration and grain yield as reported by 
Madhavilatha et al., (2005) for grain yield per plant. Number of productive tillers per plant exhibited significant positive association with panicle length indicating that it is one of the selection attribute for yield improvement as reported by Padmaja et al., (2011) and Nagaraju et al., (2013).This trait also showed positive non-significant association with number of filled grains per panicle, similarly reported by Sandhyakishore (2007), Rahman et al., (2014) and Sarker et al., (2014). Panicle length registered significant positive association with number of filled grains per panicle and grain zinc concentration as reported by Chandra et al., (2009) and Padmaja et al., (2011) for number of filled grains per panicle. This trait also exhibited positive non-significant association with 1000-grain weight and grain iron concentration, similar results reported by Chandra et al., (2009), Nandan et al., (2010) and Rahman et al., (2014) for 1000-grain weight. Number of filled grains per panicle exhibited positive non-significant association with grain iron concentration and grain zinc concentration. 1000-grain weight showed a significant positive association with grain iron concentration and grain zinc concentration.

Table.1 Phenotypic and Genotypic correlation coefficient analysis of yield, yield contributing and nutritional characters in rice

\begin{tabular}{|c|c|c|c|c|c|c|c|c|c|c|}
\hline Character & & $\begin{array}{l}\text { Days to } \\
50 \% \\
\text { flowering }\end{array}$ & $\begin{array}{l}\text { Plant } \\
\text { height }(\mathrm{cm})\end{array}$ & $\begin{array}{l}\text { No. of } \\
\text { productive } \\
\text { tillers/plant }\end{array}$ & $\begin{array}{l}\text { Panicle } \\
\text { length } \\
\text { (cm) }\end{array}$ & $\begin{array}{l}\text { No. of } \\
\text { filled } \\
\text { grains per } \\
\text { panicle }\end{array}$ & $\begin{array}{l}\text { 1000-grain } \\
\text { weight }(\mathrm{g})\end{array}$ & $\begin{array}{l}\text { Grain iron } \\
\text { concentration } \\
\text { (ppm) }\end{array}$ & $\begin{array}{l}\text { Grain zinc } \\
\text { concentration } \\
\text { (ppm) }\end{array}$ & $\begin{array}{l}\text { Grain } \\
\text { yield per } \\
\text { plant }(\mathrm{g})\end{array}$ \\
\hline \multirow{2}{*}{$\begin{array}{l}\text { Days to } 50 \% \\
\text { flowering }\end{array}$} & $\mathbf{G}$ & 1.0000 & 0.0092 & 0.0436 & -0.0717 & 0.1077 & $-0.2399 *$ & -0.0715 & -0.0225 & 0.1210 \\
\hline & $\mathbf{P}$ & 1.0000 & 0.0157 & 0.0547 & -0.0648 & $0 . .0895$ & $-0.2305^{*}$ & -0.0627 & -0.0373 & 0.1164 \\
\hline \multirow{2}{*}{$\begin{array}{l}\text { Plant Height } \\
\text { (cm) }\end{array}$} & $\mathbf{G}$ & & 1.0000 & $0.2612 * *$ & $0.3476 * *$ & $0.3058 * *$ & $0.2720 * *$ & $0.2806 * *$ & 0.1143 & 0.1587 \\
\hline & $\mathbf{P}$ & & 1.0000 & $0.2106^{* *}$ & $0.3590 * *$ & $0.2988 * *$ & $0.2112 * *$ & $0.2616^{* *}$ & 0.1247 & 0.1614 \\
\hline \multirow{2}{*}{$\begin{array}{l}\text { No. of } \\
\text { productive } \\
\text { tillers / plant }\end{array}$} & $\mathbf{G}$ & & & 1.0000 & $0.3618 * *$ & 0.1446 & $-0.3340 * *$ & -0.0735 & $-0.6398 * * *$ & $0.4295^{* *}$ \\
\hline & $\mathbf{P}$ & & & 1.0000 & $0.3142 * *$ & 0.1115 & $-0.3010 * *$ & -0.0493 & $-0.6742 * * *$ & $0.4032 * *$ \\
\hline \multirow{2}{*}{$\begin{array}{l}\text { Panicle Length } \\
\text { (cm) }\end{array}$} & $\mathbf{G}$ & & & & 1.0000 & $0.2197 *$ & 0.0678 & 0.1030 & $0.2386^{*}$ & $0.1835^{*}$ \\
\hline & $\mathbf{P}$ & & & & 1.0000 & $0.2120 *$ & 0.0550 & 0.0973 & $0.2551 * *$ & $0.1803^{*}$ \\
\hline \multirow{2}{*}{$\begin{array}{l}\text { No. of filled } \\
\text { grains/panicle }\end{array}$} & $\mathbf{G}$ & & & & & 1.0000 & $-0.3427 * *$ & 0.0971 & 0.0162 & $0.1911^{*}$ \\
\hline & $\mathbf{P}$ & & & & & 1.0000 & $-0.3198 * *$ & 0.0966 & 0.0342 & $0.1919^{*}$ \\
\hline \multirow{2}{*}{$\begin{array}{l}\text { 1000-grain } \\
\text { weight (g) }\end{array}$} & $\mathbf{G}$ & & & & & & 1.0000 & $0.2353^{*}$ & $0.3618 * *$ & 0.0073 \\
\hline & $\mathbf{P}$ & & & & & & 1.0000 & $0.2141^{*}$ & $0.3282 * *$ & 0.0083 \\
\hline \multirow{2}{*}{$\begin{array}{c}\text { Grain iron } \\
\text { concentration } \\
(\mathbf{p p m})\end{array}$} & $\mathbf{G}$ & & & & & & & 1.0000 & 0.1543 & $0.2172^{*}$ \\
\hline & $\mathbf{P}$ & & & & & & & 1.0000 & 0.1269 & $0.2139^{*}$ \\
\hline \multirow{2}{*}{$\begin{array}{c}\text { Grain zinc } \\
\text { concentration } \\
(\mathbf{p p m})\end{array}$} & $\mathbf{G}$ & & & & & & & & 1.0000 & 0.1089 \\
\hline & $\mathbf{P}$ & & & & & & & & 1.0000 & 0.1011 \\
\hline
\end{tabular}

P -represents phenotypic correlation coefficient; G- represents genotypic correlation coefficient

*Significant at 5 percent level, **Significant at 1 percent level 
Table.2 Phenotypic (P) and Genotypic (G) Path coefficient analysis of yield, yield contributing and nutritional characters in rice

\begin{tabular}{|c|c|c|c|c|c|c|c|c|c|c|}
\hline Character & & $\begin{array}{c}\text { Days to } \\
50 \% \\
\text { flowering }\end{array}$ & $\begin{array}{c}\text { Plant } \\
\text { height } \\
(\mathbf{c m})\end{array}$ & $\begin{array}{c}\text { No of } \\
\text { productive } \\
\text { tillers/plant }\end{array}$ & $\begin{array}{c}\text { Panicle } \\
\text { length } \\
(\mathrm{cm})\end{array}$ & $\begin{array}{c}\text { No of } \\
\text { filled } \\
\text { grains per } \\
\text { panicle }\end{array}$ & $\begin{array}{c}\text { 1000-grain } \\
\text { weight (g) }\end{array}$ & $\begin{array}{c}\text { Grain iron } \\
\text { concentration } \\
(\mathbf{p p m})\end{array}$ & $\begin{array}{c}\text { Grain zinc } \\
\text { concentratio } \\
\text { n (ppm) }\end{array}$ & $\begin{array}{r}\text { Grain yield } \\
\text { per plant }(g)\end{array}$ \\
\hline \multirow{2}{*}{$\begin{array}{c}\text { Days to } 50 \% \\
\text { flowering }\end{array}$} & $\mathbf{G}$ & 0.0696 & 0.0008 & 0.0596 & 0.0482 & 0.0137 & -0.0359 & -0.0113 & -0.0238 & 0.1210 \\
\hline & $\mathbf{P}$ & 0.0648 & 0.0014 & 0.0737 & 0.0407 & 0.0112 & -0.0251 & -0.0092 & -0.0411 & 0.1164 \\
\hline \multirow{2}{*}{$\begin{array}{c}\text { Plant } \\
\text { Height }(\mathrm{cm})\end{array}$} & $\mathbf{G}$ & 0.0006 & 0.0845 & 0.3569 & -0.4884 & 0.0389 & 0.0013 & 0.0443 & 0.1206 & 0.1587 \\
\hline & $\mathbf{P}$ & 0.0010 & 0.0904 & 0.2835 & -0.4281 & 0.0373 & 0.0014 & 0.0383 & 0.1374 & 0.1614 \\
\hline \multirow{2}{*}{$\begin{array}{c}\text { No. of } \\
\text { productive } \\
\text { tillers / plant }\end{array}$} & $\mathbf{G}$ & 0.0030 & 0.0221 & 1.3661 & -0.2436 & 0.0184 & -0.0500 & -0.0116 & -0.6749 & 0.4295 \\
\hline & $\mathbf{P}$ & 0.0035 & 0.0190 & 1.3465 & -0.1973 & 0.0139 & -0.0328 & -0.0072 & -0.7425 & 0.4032 \\
\hline \multirow{2}{*}{$\begin{array}{c}\text { Panicle } \\
\text { Length }(\mathrm{cm}) \\
\end{array}$} & $\mathbf{G}$ & -0.0050 & 0.0613 & 0.4943 & -0.6733 & 0.0279 & 0.0102 & 0.0163 & 0.2518 & 0.1835 \\
\hline & $\mathbf{P}$ & -0.0042 & 0.0616 & 0.4231 & -0.6280 & 0.0265 & 0.0060 & 0.0143 & 0.2810 & 0.1803 \\
\hline \multirow{2}{*}{$\begin{array}{c}\text { No. of filled } \\
\text { grains/panicle }\end{array}$} & $\mathbf{G}$ & 0.0075 & 0.0259 & 0.1975 & -0.1479 & 0.1271 & -0.0513 & 0.0153 & 0.0170 & 0.1911 \\
\hline & $\mathbf{P}$ & 0.0058 & 0.0270 & 0.1502 & -0.1331 & 0.1250 & -0.0348 & 0.0142 & 0.0377 & 0.1919 \\
\hline \multirow{2}{*}{$\begin{array}{l}\text { 1000-grain } \\
\text { weight (g) }\end{array}$} & $\mathbf{G}$ & -0.0167 & 0.0007 & -0.4563 & -0.0456 & -0.0436 & 0.1498 & 0.0372 & 0.3818 & 0.0073 \\
\hline & $\mathbf{P}$ & -0.0149 & 0.0012 & -0.4053 & -0.0345 & -0.0400 & 0.1088 & 0.0314 & 0.3616 & 0.0083 \\
\hline \multirow{2}{*}{$\begin{array}{c}\text { Grain iron } \\
\text { concentration } \\
(\mathbf{p p m})\end{array}$} & $\mathbf{G}$ & -0.0050 & 0.0237 & -0.1004 & -0.0694 & 0.0123 & 0.0353 & 0.1579 & 0.1627 & 0.2172 \\
\hline & $\mathbf{P}$ & -0.0041 & 0.0237 & -0.0664 & -0.0611 & 0.0121 & 0.0233 & 0.1466 & 0.1398 & 0.2139 \\
\hline \multirow{2}{*}{$\begin{array}{c}\text { Grain zinc } \\
\text { concentration } \\
(\mathbf{p p m})\end{array}$} & $\mathbf{G}$ & -0.0016 & 0.0097 & -0.8740 & -0.1607 & 0.0021 & 0.0542 & 0.0244 & 1.0549 & 0.1089 \\
\hline & $\mathbf{P}$ & -0.0024 & 0.0113 & - 0.9077 & -0.1602 & 0.0043 & 0.0357 & 0.0186 & 1.1015 & 0.1011 \\
\hline
\end{tabular}

Phenotypic residual effect $=0.6169$, Genotypic residual effect $=0.5834$, BOLD values are direct effects

$\mathrm{P}=$ represents Phenotypic correlation coefficient, $\mathrm{G}=$ represents Genotypic correlation coefficient

\section{Path coefficient analysis}

Correlation gives only the relation between two variables whereas path coefficient analysis allows separation of the direct effect and their indirect effects through other attributes by partitioning the correlations (Wright, 1921). Based on the data presented the genotypic and phenotypic correlations were estimated to determine direct and indirect effects of yield and yield contributing characters. If the correlation coefficient between a casual factor and the effect is almost equal to its direct effect, it explains the true relationship and a direct selection through this trait may be useful. If the correlation coefficient is positive, but the direct effect is negative or negligible, the indirect effects appear to be the cause of that positive correlation. In such situation the other factors are to be considered simultaneously for selection. However if the correlation coefficient is negative but direct effect is positive and high, a restriction has to be imposed to nullify the undesirable indirect effects in order to make use of direct effect.

Path coefficient analysis (Table 2) revealed that number of productive tillers per plant exerted the highest positive direct effect on grain yield followed by grain zinc concentration, grain iron concentration, number of filled grains per panicle, 1000grain weight, plant height, days to $50 \%$ flowering indicating that the selection for this characters was likely to bring about an overall improvement in grain yield per plant directly. Therefore, it is suggested that preference should be given to these characters in the selection programme to isolate superior lines with genetic potentiality for high yield in rice genotypes. These results are in agreement with Padmaja et al., (2011), Basavaraja et al., (2012) and Mohanty et al., (2012) for days to $50 \%$ flowering and plant height, Padmaja et al., (2011), Lingaiah et al., (2014) and 
Rahman et al.,(2014) for number of productive tillers per plant and 1000-grain weight, Padmaja et al., (2011), Mohanty et al., (2012), and Sarker et al., (2014) for number of filled grains per panicle, Bekele et al., (2013) for grain iron concentration and grain zinc concentration. Negative direct effect on grain yield was exhibited by panicle length as reported by Krishna et al., (2008), Chandra et al., (2009), Garg et al., (2010), Padmaja et al., (2011) and Patel et al., (2014).

Analysis of results obtained from character association and path analysis indicated that 1000 -grain weight, plant height, days to $50 \%$ flowering, grain zinc concentration exerted positive direct effect on grain yield per plant but it had Positive non- significant association with yield which might be due to positive indirect effects manifested through other component traits. But number of productive tillers per plant, panicle length, number of filled grains per panicle, Grain iron concentration displayed significant positive correlation as well as positive direct effect on grain yield per plant. The positive direct effect of these traits on yield resulted in strong genetic correlation. Hence, due emphasis should be given to these traits in formulating selection criteria to bring yield as well as grain quality improvement.

\section{References}

Babu, V.R., Shreya, K., Dangi, K.S., Usharani, G and Nagesh, P. 2012. Genetic variability studies for qualitative and quantitative traits in popular rice (Oryza sativa L.) hybrids of India. International Journal of Scientific and Research Publications. 2 (6): 1-5.

Basavaraja, J., Asif, M., Mallikarjun, S.K and Gangaprasad, S. 2013. Variability, heritability and genetic advance for yield and yield attributing characters in different local rice (Oryza sativa L.) cultivars. Asian Journal of Bio Science. 8 (1): 60-62.

Bekele, B.D., Rakhi, S., Naveen, G.K., Kundur, P.J and Shashidhar, H.E. 2013. Estimation of genetic variability and correlation studies for grain zinc concentrations and yield related traits in selected rice (Oryza sativa L.) genotypes. Asian Journal of Experimental Biology.4 (3): 391-397.

Chandra, B.S., Reddy, T.D., Ansari, N.A and Kumar, S.S., 2009 Correlation and path analysis for yield and yield components in rice (Oryza sativa L.). Agricultural Science Digest. 29 (1): 45-47.

Dewey, J.R., and Lu, K.H. 1959. Correlation and path coefficient analysis of components of crested wheat grass seed production. Agronomy Journal. 51: 515518.

Ekka, R.E., Sarawgi, A.K and Kanwar, R.R. 2011. Correlation and path analysis in traditional rice accessions of Chhattisgarh. Journal of Rice Research. 4 (1\& 2): 11-18.

Gangashetty, P.I., Salimath, P.M and Hanamaratti, N.G. 2013. Genetic variability studies in genetically diverse non-basmati local aromatic genotypes of rice (Oryza sativa L.). Rice Genomics and Genetics. 4 (2): 4-8.

Garg, P., Pandey, D.P and Singh, D. 2010. Correlation and path analysis for yield and its components in rice (Oryza Sativa L.). Crop Improvement. 37 (1): 46-51.

Krishna, L., Raju, C.H.D and Raju, C.H.S. 2008. Genetic variability and correlation for yield and grain quality characters of rice germplasm. The Andhra Agricultural Journal. 55 (3): 276-279.

Lingaiah, N., Venkanna, V., Cheralu, C and Chandra, B.S.2014. Correlation and Path analysis for yield and yield 
attributes in mid early group genotypes of rice (Oryza sativa L.). International Journal of Innovative Science, Engineering \& Technology. Vol. 1 Issue 9.

Madhavilatha, L., Sekhar, M.R., Suneetha, Y and Srinivas, T. 2005. Genetic variability, correlation and path analysis for yield and quality traits in rice (Oryza sativa L.). Research on Crops. 6 (3): 527-537.

Mohanty, N.M., Sekhar, R., Reddy, D.M and Sudhakar, P. 2012. Genetic variability and character association of agromorphological and quality characters in rice. Oryza. 49 (2): 88-92.

Nandan, R., Sweta and Singh, S.K. 2010. Character Association and path analysis in rice (Oryza sativa L.) genotypes. World Journal of Agricultural Sciences. 6 (2): 201-206.

Padmaja, D., Radhika, K., Rao, L.V.S and Padma, V. 2011.Correlation and path analysis in rice germplasm. Oryza. 48 (1): 69-72.

Patel*, J.R., Saiyad, M.R., Prajapati, K.N., Patel, R.A and Bhavani R.T. 2014. Genetic variability and character association studies in rainfed upland rice (Oryza sativa L.). Electronic Journal of Plant Breeding. 5(3): 531537.

Rahman, M.A., Hossain, M.S., Chowdhury*, I.F., Matin, M.A and Mehraj, H. 2014. Variability study of advanced fine rice with correlation, path coefficient analysis of yield and yield contributing characters. International journal of
Applied Science and Biotechnology. Vol 2(3): 364-370.

Rao, V.T., Mohan, Y.C., Bhadru, D., Bharathi, D and Venkanna, V. 2014.Genetic variability and association analysis in rice. International Journal of Applied Biology and Pharmaceutical Technology. vol.5, issue 2.

Reddy, G.E., Suresh, B.G., Sravan, T and Reddy, P.A. 2013.Interrelationship and cause-effect analysis of rice genotypes in North East plain zone. The Bioscan. 8 (4): 1141-1144.

Sandhyakishore, N., Ansari, N.A., Ravindra Babu, V., Shobha Rani, N., Rao, L.V.S and Ravinchandran. 2007. Correlation and path analysis in aromatic and nonaromatic rice genotypes. Agriculture Science Digest. 27 (2): 122 - 124.

Sarker, Md. M., Hassan, L., Islam, M.M., Rashid, Md. M and Seraj, S. 2014. Correlation and Path coefficient analysis of some exotic early maturing rice (Oryza sativa L.) lines. Journal of Bioscience and Agriculture Research. Vol. 01 (01): 01-07.

Singh, R.K., and Chaudhary, B.D. 1979. Biometrical Methods in Quantitative Genetic Analysis. Kalyani Publishers, New Delhi, pp. 215 - 218.

Sravan, T., Rangare, N.R., Sursh, B.G and Kumar, S.R. 2012.Genetic Variability and character association in rainfed upland rice (Oryza sativa L.). Journal of Rice Research. vol. 5 No. 1\&2.

Wright, S., 1921. Correlation and Causation. Journal of Agricultural Research. 20: $557-585$.

\section{How to cite this article:}

Ramya Rathod, D. Sanjeeva Rao, V. Ravindra Babu and Bharathi, M. 2017. Correlation and Path Coefficient Analysis for Yield, Yield Attributing and Nutritional Traits in Rice (Oryza sativa L.). Int.J.Curr.Microbiol.App.Sci. 6(11): 183-188.

doi: https://doi.org/10.20546/ijcmas.2017.611.023 